chloric acid in the TBP phase by E.M.F. measurements on the cell:

$$
\mathrm{H}_{2}, \mathrm{Pt} \mid \mathrm{HCl}(m) \text { in } \mathrm{TBP} \mid \mathrm{AgCl}, \mathrm{Ag}
$$

We have shown that the hydrogen and silver/silver chloride electrodes are reversible in TBP.

For the corresponding aqueous solution cell, the E.M.F. is given by:

$$
E=E_{0}-0.05914 \log a_{\mathrm{HCl}}
$$

For the TBP solution cell just mentioned it is given by:

$$
E^{\prime}=E_{0}^{\prime}-0 \cdot 05914 \log a_{\mathrm{HCl}}^{\prime}
$$

If the solutions in the two cells are in partition equilibrium, then from the first law of thermodynamics, $E=E^{\prime}$. Hence:

$$
E^{\prime}-E_{0}=-0.05914 \log a_{\mathrm{HCl}}
$$

The accepted value of $E_{0}$ is $0 \cdot 222 \mathrm{~V}$ (ref. 3).

Fig. 1 shows $E^{\prime}-E_{0}$ (circles) and $-0.05914 \log _{10} a_{\mathrm{HCl}}$ (solid line based on Hesford and McKay's results', which cover the required concentration range), plotted against the concentration of hydrochloric acid in the TBP phase. The agreement is good except at very low concentrations where the measurements become difficult.

$$
\begin{aligned}
& \text { H. A. C. McKay } \\
& \text { J. H. Miles }
\end{aligned}
$$

Atomic Energy Research Establishment, Harwell, Berks.

${ }^{1}$ See, for example, Glueckauf, E., McKay, H. A. C., and Mathieson, A. R., Trans. F'arad. Soc., 47, 437 (1951).

'Peppard, D. F., Mason, G. W., and Maier, J. L., J. Inorg. Nucl. Chem., 3, 215 (1956). Irving, H. M. N. H., and Edgington, D. N., ibid., 10, 306 (1959). Baldwin, W. H., Higgins, C. E., and Soldano, B. A., J. Phys. Chem., 63, 118 (1959). Hesford, E., and McKay, H. A. C., J. Inorg. Nucl. Chem., 13, 156 (1960). Kertes, A. S., ibid., 14, 104 (1960). Naito, K., and Suzuki, T., J. Phys. Chem., 66, 989 (1962).

${ }^{3}$ Ives, D. J. G., and Janz, G. J., Reference Electrodes, 196 (Academic Press, $1961)$

\section{Pertechnic Acid : an Aperiodic Variation in Acid Strength}

For a given oxidation level the oxy-acids in a given sub-group of the periodic table are normally found to exhibit a regular variation in acid strengths. In group VII, for example, Cobble ${ }^{1}$ lists the logical $p \mathrm{~K}$ values as $-2 \cdot 25,(-1.5)$ and -1.25 for $\mathrm{HMnO}_{4}, \mathrm{HTcO}_{4}$ (estimated, with due regard for the lanthanide contraction) and $\mathrm{HReO}_{4}$. The general behaviour of pertechnic acid in aqueous neutralimetry certainly is consistent with that of a monoprotic and 'relatively' strong acid.

On the other hand, Kertes and Beck ${ }^{2}$ conclude a paper on the tributyl phosphate extraction of Te(VII) with the dilemma: "Consequently, the origin of the different extractabilities of $\mathrm{HTcO}_{4}$ and $\mathrm{HReO}_{4}$ found, lies in their different acid strengths and it follows that $\mathrm{HReO}_{4}$ is a stronger acid than $\mathrm{H}^{\prime} \mathrm{TcO} \mathrm{O}_{4}$. The respective position of the elements in the Periodic Table definitely suggests the opposite. This discrepancy shows that, although the acid strength is an important factor governing the extractability of acid by oxygen containing extractants, it is probably not the only one. Consequently, some other factors not yet known seem to be more determining".

The sometime red colour of $\mathrm{HTcO}_{4}$, the unexplored possibility of mesopertechnetates, the $\left(\mathrm{H}^{+}\right)$-dependence of certain liquid-liquid extractions of Tc(VII) (refs. 3 and 4), the nature of $R e / T c$ separations on anion-exchange resins, the polarographic and the spectrophotometric behaviour of pertechnetate ion versus $p \mathrm{H}$ (refs. 3 and 4)all have been examined or are now being examined in this laboratory. Each of these phenomena has an obviously requisite, or a more subtly probable, dependence on the ionization constant of pertechnic acid.

The acid ionization constant itself is now being measured precisely and as a function of temperature. From our earlier results ${ }^{4}, K_{\text {ion }}$ of $\mathrm{HTcO}_{4}{ }^{*}$ at $25 \cdot 4^{\circ} \mathrm{C}$ is about $5 \pm 2$ $\times 10^{-1}$. This value of 0.5 is nearly one-hundred-fold less than the anticipated value of 32 , and is well below the $K_{\text {ion }}$ of 18 for $\mathrm{HReO}_{4}$. We also find that this low value is requisite for a logical explanation of the ether extraction of pertechnetate from aqueous media of various $p \mathrm{H}$ (ref. 4).

Of course, this surprisingly aperiodic behaviour may possibly be explained in terms of dimerization, hydration, or similar, factors. Present research is directed toward seeking this explanation, and the expression $\mathrm{HTcO}_{4} *$ may represent an over-simplification respecting the measured acidity. Our acid was prepared by the dissolution in distilled water of $\mathrm{Tc}_{2} \mathrm{O}_{7}$, made by the combustion in oxygen of $\mathrm{Tc}$ [99] obtained in 99.9 per cent purity from the Oak Ridge National Laboratory.

Charles L. Rulfs Roland F. Hirsch

Department of Chemistry, Richard A. Pacer

University of Michigan, Ann Arbor.

${ }^{1}$ Cobble, J. W., in Kolthoff and Elving, Treatise on Analytical Chemistry, Part 2, 6 (Interscience-Wilcy, New York, 1963).

${ }^{3}$ Kertes, A. S., and Beck, A., Proe. Seventh I.C.C.C., Stockholm, 352 (June 1962).

salaria, G. B. S., Rulfs, C. L., and Elving, P. J., J. Chem. Soc. and Anal. Chem. (in the press), and unpublished results.

${ }^{4}$ Rulfs, C. L., Hirsch, R. F., Pacer, R. A., and Kitson, D. A. (unpublished results).

\section{Trace Analysis by Combined Chromatographic Techniques}

The application of gas chromatography to the determination of trace impurities may be considerably extended by using a combination of chromatographic techniques. We may illustrate this by the following example in which concentrations of alkenes in alkanes as low as 1 in $10^{8}$ have been readily and precisely determined.

$n$-Heptane was first freed from alkenes by passing the liquid through a column of alumina modified with silver nitrate (about $10 \mathrm{~g}$ of packing per $100 \mathrm{~g}$ of heptane). In the first series of experiments, quantities of 1 -hexene and 1-heptene ranging from 1 to $10 \mathrm{mg}$ each were added to $100 \mathrm{~g}$ of the purified heptane. The resulting samples were then forced under slight nitrogen pressure and at room temperature through a similar modified alumina column ( $3 \mathrm{~mm}$ internal diameter and $1 \mathrm{~g}$ packing). When tho column was free of liquid its temperature was raised to $75^{\circ} \mathrm{C}$ and nitrogen passed through to elute the last traces of heptane. The hexene and heptene were then displaced from the column by a stream of nitrogen saturated with 1-octene. The resulting chromatogram (gas-density detector) is shown in Fig. 1, the dotted lines representing the hexene and heptene steps. The lengths of these steps were found to be proportional to the quantities of alkenes introduced into the heptane, so that this method may be used directly for concentrations down to 1 in $10^{5}$.

In the second series of experiments $1 \mu \mathrm{g}$ quantities of 1-hexene, 1-heptene and 2-heptene were addod to $100 \mathrm{~g}$ of purified heptane. Such samples were treated as in the first

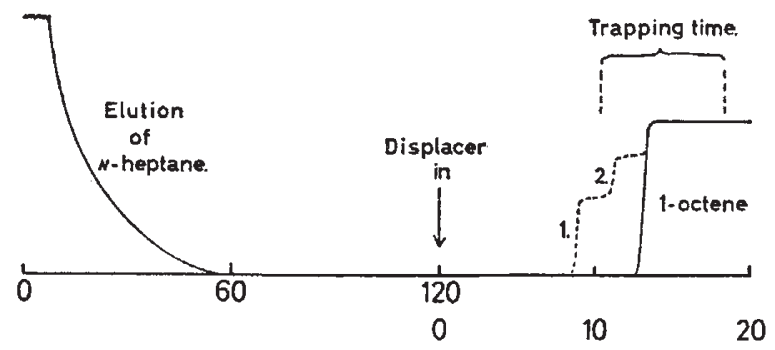

Time (min).

Fir. 1. Elution of last traces of $n$-heptano and displacement of alkcnes (step 1 = hexene, step 2 = heptene) from a column of alumina modified 